\title{
Penyelesaian Perkara Anak Sebagai Pelaku dan Korban Ditinjau Dari Asas Kepentingan Terbaik Bagi Anak
}

\author{
Hadibah Zachra Wadjo $^{1 *}$, Elias Zadrach Leasa ${ }^{2}$, Denny Latumaerissa ${ }^{3}$, Judy \\ Marria Saimima ${ }^{4}$. \\ 1,2,3,4. Fakultas Hukum Universitas Pattimura, Ambon, Indonesia \\ *E-mail: diba.wajo71@gmail.com
}

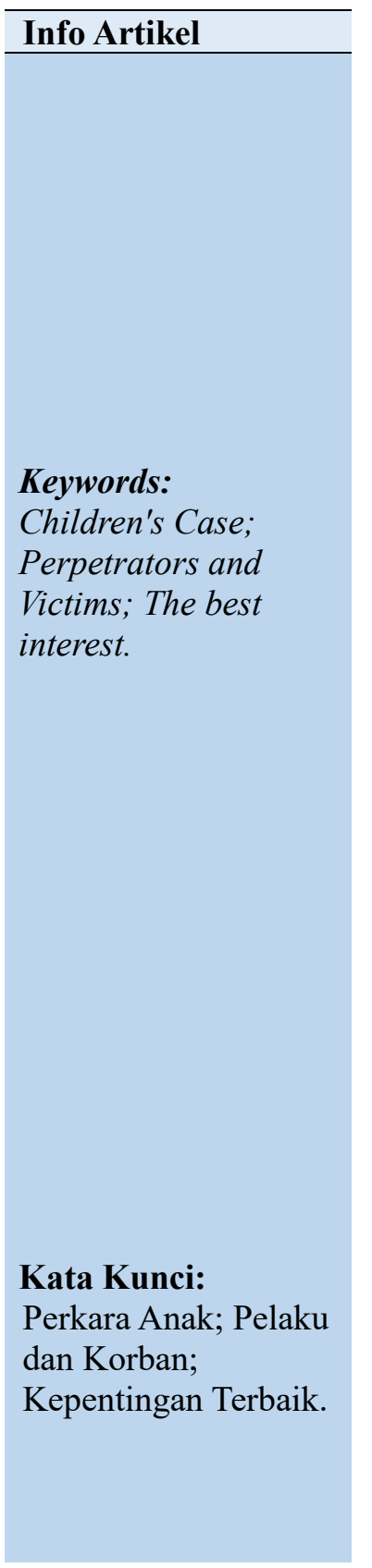

\begin{abstract}
In reality, specifically for the principle of the best interests of children who are accommodated in the Aanak Criminal Justice System Act not yet maximized to be applied in cases of children who are dealing with the law both against children as perpetrators and children as victims, which in the settlement of losses suffered by children as a victim of a criminal offense, it has not been concretely felt. Based on the explanation above, the problem that the writer wants to analyze is Is the settlement of the case of children considering the best interests of the child as the perpetrator and the child as the victim? Constraints in fulfilling the best interests principle for children as perpetrators and children as victims. The research method used is a type of empirical juridical research. The results showed that the fulfillment of the best interests of children in the case of children in conflict with the law must be supported by all relevant stakeholders so that children's rights can be implemented at all stages of the case inspection in accordance with the mandate of the Aanak Criminal Justice System Law and the Law related, it is not enough there, the fulfillment of the best interests must also continue to be supported back to the community. Obstacles in fulfilling the best interests of cases of children in conflict with the law, namely the lack of investigators for the protection of women and children, inadequate facilities or infrastructure, human resources both for women and children protection investigators and for assisting victims who are not yet qualified, lack of budget in case settlement children in conflict with the law.
\end{abstract}

Abstrak
Pada kenyataannya, khusus untuk prinsip kepentingan terbaik anak-
anak yang ditampung dalam Undang-Undang Sistem Peradilan
Pidana Aanak belum dimaksimalkan untuk diterapkan dalam kasus
anak yang berurusan dengan hukum baik terhadap anak-anak sebagai
pelaku dan anak-anak sebagai korban, yang dalam penyelesaian
kerugian yang diderita anak-anak sebagai korban tindak pidana, hal
itu belum dirasakan secara konkret. Berdasarkan penjelasan di atas,
masalah yang penulis ingin analisis adalah apakah penyelesaian
kasus anak mempertimbangkan kepentingan terbaik anak sebagai
pelaku dan anak sebagai korban? Kendala dalam memenuhi prinsip
kepentingan terbaik bagi anak-anak sebagai pelaku dan anak-anak


sebagai korban. Metode penelitian yang digunakan adalah jenis penelitian yuridis empiris. Hasil penelitian menunjukkan bahwa pemenuhan kepentingan terbaik anak-anak dalam kasus anak-anak yang bertentangan dengan hukum harus didukung oleh semua pemangku kepentingan yang relevan sehingga hak-hak anak dapat diimplementasikan pada semua tahap inspeksi kasus sesuai dengan mandat dari Hukum Sistem Peradilan Pidana Aanak dan UU terkait, tidak cukup di sana, pemenuhan kepentingan terbaik juga harus terus didukung kembali ke masyarakat. Hambatan dalam memenuhi kepentingan terbaik kasus anak-anak yang bertentangan dengan hukum, yaitu kurangnya penyelidik untuk perlindungan perempuan dan anak, fasilitas atau infrastruktur yang tidak memadai, sumber daya manusia baik untuk penyidik Perlindungan Perempuan dan Anak dan untuk membantu korban yang tidak belum memenuhi syarat, kurangnya anggaran dalam kasus penyelesaian anak-anak yang bertentangan dengan hukum.

\section{A. PENDAHULUAN}

Anak adalah bagian dari generasi muda sebagai salah satu sumber daya manusia yang merupakan potensi dan penerus cita-cita perjuangan bangsa, yang memiliki peranan strategis dan mempunyai ciri dan sifat khusus, memerlukan pembinaan serta perlindungan dalam rangka menjamin pertumbuhan dan perkembangan fisik, mental secara utuh, serasi, selaras dan seimbang. Untuk melaksanakan pembinaan dan memberikan perlindungan terhadap anak, diperlukan dukungan baik yang menyangkut kelembagaan maupun perangkat hukum yang lebih mantap dan memadai, oleh karena itu ketentuan mengenai penyelenggaraan pengadilan bagi anak perlu dilakukan secara khusus. ${ }^{1}$

Seperti dijelaskan didalam Undang-Undang Sistem Peradilan Pidana Anak (selanjutnya disebut UU SPPA), istilah anak nakal tidak dikenal lagi, tetapi digunakan istilah anak yang berkonflik dengan hukum. Pasal 1 angka 3 menentukan bahwa Anak yang berkonflik dengan hukum adalah anak yang telah berumur 12 (dua belas) tahun tetapi belum berumur 18 (delapan belas) tahun. Sebelumnya pada Pasal 1 angka 2 UU ini menentukan bahwa Anak yang Berhadapan dengan Hukum adalah anak yang berkonflik dengan hukum, anak yang menjadi korban tindak pidana, dan anak yang menjadi saksi tindak pidana.

Pasal 2 UU SPPA, menentukan bahwa Sistem Peradilan Pidana Anak, dilaksanakan berdasarkan asas:

a) Perlindungan;

b) Keadilan;

c) Nondiskriminasi;

d) Kepentingan terbaik bagi anak;

e) Pembinaan dan pembimbingan anak;

f) Proporsional;

g) Perampasan kemerdekaan dan;

h) Pemidanaan

Namun pada realitasnya, khusus untuk asas kepentingan terbaik bagi anak yang terakomodir didalam UU SPPA belum maksimal untuk diterapkan pada kasus-kasus anak yang berhadapan dengan hukum (selanjutnya disebut $\mathrm{ABH}$ ) baik terhadap anak sebagai

${ }^{1}$ Makarao, M. T., dkk. (2013). Hukum Perlindungan Anak dan Penghapusan Kekerasan Dalam Rumah Tangga, Jakarta: Rineka Cipta, h. 1. 
pelaku dan anak sebagai korban, yang mana dalam penyelesaiannya kerugian yang dialami anak sebagai korban suatu tindak pidana, belum secara konkret dirasakan. Hal ini berarti perlindungan terhadap anak sebagai korban tindak pidana lebih banyak merupakan perlindungan yang abstrak atau perlindungan tidak langsung, Sistem sanksi dan pertanggungjawaban tindak pidana tidak tertuju pada perlindungan korban secara langsung dan konkret. Namun justru tindakan yang diambil oleh para pihak dalam penyelesaian menimbulkan problem atau permasalahan dalam menjamin kepentingan terbaik dari anak itu sendiri.

Terkait dengan anak sebagai pelaku tindak pidana, dari perspektif kepentingan terbaik bagi anak sebagaimana terakomodir didalam UU SPPA juga mempunyai persoalan tersendiri, yang mana dalam penerapannya seringkali apa yang diamanatkan didalam UU ini tidak dapat direalisasikan secara menyeluruh, misalnya saja dari segi sarana dan prasarana penegakan hukum $\mathrm{ABH}$ tidak mendukung untuk mewujudkannya.

Berdasarkan uraian pendahuluan tersebut di atas, maka perlu dilakukan penelitian dengan permasalahan bahwa: "Apakah penyelesaian perkara anak sudah mempertimbangkan kepentingan terbaik bagi anak sebagai pelaku dan anak sebagai korban, dan Kendala-kendala dalam pemenuhan asas kepentingan terbaik bagi anak sebagai pelaku dan anak sebagai korban".

\section{B. METODE PENELITIAN}

Penelitian sebagai salah satu proses yang dilakukan untuk melengkapi penulisan. Oleh karena itu, pada dasarnya bahwa metode penelitian ini digunakan untuk mendukung penelitian agar benar-benar teruji. Oleh sebab itu, metode merupakan prosedur atau cara untuk mengetahui sesuatu berdasarkan langkah-langkah yang sistematis. Sebaliknya metodologi merupakan kegiatan mempelajari keteraturan-keteraturan yang terdapat di dalam metode. Dalam mencari suatu jawaban, metode penelitian seringkali digunakan sebagai alat untuk membantu menjawab permasalahan dalam penelitian melalui prosedur, cara dan teknik melalui langkah-langkah penelitian, dan dengan menggunakan penalaran dan berpikir yang logis-analitis. Bagi suatu penelitian hukum, substansi salah satunya yaitu penelitian yang bersifat yuridis empiris. Berdasarkan judul dan permasalahan diatas maka, jenis penelitian yang digunakan dalam penulisan ini adalah yuridis empiris. Jenis penelitian ini adalah jenis penelitian yang secara spesifik melihat pemenuhan kepentingan terbaik bagi anak yang berhadapan dengan hukum

\section{PEMBAHASAN}

\section{Penyelesaian Perkara Anak sebagai Pelaku dan Anak Sebagai Korban Ditinjau dari Asas Kepentingan Terbaik Bagi Anak}

Banyaknya perkara $\mathrm{ABH}$ (baik pelaku anak maupun anak sebagai korban) yang terjadi di Indonesia dianggap sebagai salah satu indikator buruknya kualitas perlindungan anak, sebagaimana yang terjadi pada Kota Ambon maupun kabupaten Kepulauan Aru (Dobo), yang mana hal ini penulis dapati ketika melakukan peneltian yang akan penulis jelaskan pada tabel berikut ini : 
Tabel 1.

Perkara ABH Pada Polres P.Ambon dan P.P Lease

Tahun 2017-2019

\begin{tabular}{|l|l|c|c|c|}
\hline \multirow{2}{*}{ No } & \multicolumn{1}{|c|}{ Tindak Pidana } & \multicolumn{3}{|c|}{ Tahun } \\
\cline { 3 - 5 } & & 2017 & 2018 & 2019 \\
\hline 1. & Kekerasan terhadap Anak & 53 & 55 & 48 \\
\hline 2. & Pencabulan terhadap anak & 25 & 34 & 22 \\
\hline 4 & Persetubuhan terhadap anak & 37 & 63 & 38 \\
\hline 5 & Perkosaan terhadap anak & 4 & 5 & 10 \\
\hline 6 & KDRT & 45 & 57 & 27 \\
\hline
\end{tabular}

Sumber data : Polres Pulau Ambon dan PP. Lease (Data Terakhir Oktober 2019)

Tabel 2.

Anak yang berhadapan dengan Hukum (ABH) Pada

Polres Kepulauan Aru

Tahun 2017-2019

\begin{tabular}{|l|l|c|c|c|}
\hline \multirow{2}{*}{ No } & \multicolumn{2}{|c|}{ Tindak Pidana } & \multicolumn{3}{|c|}{ Tahun } \\
\cline { 3 - 5 } & & 2017 & 2018 & 2019 \\
\hline 1. & Kekerasan terhadap Anak & 25 & 27 & 22 \\
\hline 2. & Pencabulan terhadap anak & 30 & 35 & 32 \\
\hline 4 & Persetubuhan terhadap anak & 35 & 60 & 40 \\
\hline 5 & Perkosaan terhadap anak & 8 & 10 & 12 \\
\hline 6 & KDRT & 48 & 55 & 37 \\
\hline
\end{tabular}

Sumber data : Polres Kepulauan Aru (Data Terakhir Oktober 2019)

Berdasarkan kedua tabel di atas, dapat ditunjukan bahwa data perkara ABH yang diperoleh baik dari Polres P. Ambon dan Polres PP Lease serta Polres Kepulauan Aru, tidak ada klasifikasi anak sebagai pelaku tindak pidana, atau dengan kata lain tidak ada statistik kriminal yang secara khusus didalamnya tergambarkan kualifikasi anak sebagai pelaku tindak pidana. Padahal realitas yang terjadi untuk perkara $\mathrm{ABH}$ bukan saja melibatkan anak sebagai korban, tetapi didalamya juga melibatkan anak sebagai pelaku suatu tindak pidana.

Terkait dengan perkara $\mathrm{ABH}$, proses penyidikan dilakukan oleh penyidik yang ditetapkan berdasarkan keputusan kepala kepolisian atau pejabat lain yang ditunjuk oleh Kepala Kepolisian RI sedangkan penuntutan dilakukan oleh Penuntut Umum yang ditetapkan berdasarkan Keputusan Jaksa Agung atau pejabat lain yang ditunjuk oleh Jaksa Agung.

Dalam melakukan penyelidikan terhadap perkara anak (pelaku anak), penyidik wajib meminta pertimbangan maupun saran-saran dari pembimbing kemasyarakatan setelah tindak pidana dilaporkan atau diadukan, kemudian menyerahkan hasil penelitian kemasyarakatan paling lama 3 hari sejak permintaan penyidik. Dalam melakukan pemeriksaan terhadap anak korban penyidik wajib meminta laporan sosial dari pekerja sosial atau tenaga kesejahtaraan sosial setelah tindak pidana dilaporkan; selanjutnya terhadap anak yang diajukan sebagai anak yang berkonflik hukum $(\mathrm{ABH})$ pada tingkat 
penyidikan, penuntutan dan dan pemeriksaan perkara anak di pengadilan wajib diupayakan diversi.

Diversi adalah pengalihan penyelesaian perkara anak dari proses peradilan pidana di luar proses peradilan pidana, dan terhadap proses tersebut dengan syarat-syarat sebagai berikut :

1) Diancam pidana penjara di bawah 7 (tujuh) tahun;

2) Bukan pengulangan tindak pidana;

Proses Diversi melibatkan anak, orang tua, korban, dan atau orang tua/wali, pembimbing kemasyarakatan dan pekerja sosial profesional berdasarkan pendekatan keadilan restorative justice yang mengadung arti bahwa penyelesaian perkara tindak pidana yang melibatkan pelaku, korban dan pihak-pihak lain terkait untuk bersama-sama mencari penyelesaian yang adil dengan menekankan pemulihan kembali pada keadaan semula.

Dari hasil kesepakatan diversi perdamaian dapat berupa: dengan atau ganti kerugian, penyerahan kembali kepada orang tua/wali, keikut sertaan dalam pendidikan/pelatihan dilembaga pendidikan atau LPKS, pelayanan masyarakat. Dalam hal kesepakatan tercapai, maka setiap pejabat yang bertanggung jawab dalam pelaksanaan diversi untuk diterbitkan penghentian penyidikan, penghentian penuntutan, penghentian pemeriksaan perkara dan bilamana tercapai maka proses pemeriksaan dilanjutkan. Selanjutnya dalam hal tidak terjadi kesepakatan dalam waktu yang ditentukan maka pembimbing kemasyakatan segera melaporkan kepada pejabat untuk menindaklanjuti proses pemeriksaan.

Penyidik, Penuntut Umum, Pembimbing Kemasyarakatan dan atau pemberi bantuan hukum dan petugas lainnya dalam memeriksa perkara anak, anak korban dan atau anak saksi tidak memakai toga atau atribut kedinasan (Pasal 22 UU SPPA), kemudian dalam setiap tingkatan pemeriksaan anak wajib diberikan bantuan hukum dan didampingi oleh pembimbing kemasyarakatan atau pendamping dengan ketentuan yang berlaku; berikut:

Bahwa terkait penahanan terhadap anak (Pasal 32 UU SPPA) adalah sebagai

1) Penahanan terhadap anak tidak boleh dilakukan dalam hal memperoleh jaminan dari orang tua atau lembaga bahwa anak tidak melarikan diri, menghilangkan barang bukti atau merusak barang bukti atau tidak akan mengulangi tindak pidana;

2) Penahananan dapat dilakukan dengan syarat:

a) Umur anak 14 (empat belas) tahun;

b) Diduga melakukan tindak pidana dengan ancaman pidana penjara selama 7 (tujuh) tahun atau lebih.

Penahanan terhadap anak tentunya berbeda pula dengan terdakwa (dewasa) dan terhadap penahanan terhadap anak yang berkonflik hukum tersebut yakni sebagai berikut:

1) Penahanan oleh Penyidik paling lama 7 (tujuh) hari dan dapat diperpanjang oleh Penuntut Umum, selama 8 (delapan) hari; sedangkan terhadap terdakwa dewasa 20 (dua puluh) hari dengan perpanjangan 40 (empat puluh) hari;

2) Penahanan oleh Penuntut Umum, paling lama 5 (lima) hari kemudian dapat diperpanjang oleh Hakim selama 5 (lima) hari sedangkan terhadap terdakwa dewasa 20 (dua puluh) Hari dan diperpanjang selama 30 (tiga puluh) hari; 
3) Penahanan Hakim selama 10 hari kemudian diperpanjang selama 15 (lima belas) hari oleh Ketua PN, sedangkan terdakwa dewasa adalah 30 (tiga puluh) hari dan dapat diperpanjang selama 60 (enam puluh) hari.

Pemeriksaan di sidang pengadilan terhadap anak dalam tingkat pertama dilakukan dengan hakim tunggal, namun Ketua Pengadilan dalam pemeriksaan perkara anak dengan hakim majelis dalam hal tindak pidana yang diancam pidana penjara 7 tahun atau lebih sulit pembuktiannya. Hakim dalam memeriksa perkara anak dalam sidang anak dinyatakan tertutup untuk umum kecuali pembacaan putusan. Kemudian dalam peroses persidangan (Pasal 55 UU SPPA) Hakim wajib memerintahkan orang tua/wali atau pendamping atau pemberi bantuan hukum lainnya; dalam hal orang tua,wali atau pendamping tidak hadir, sidang dilanjutkan dengan didampingi advokat atau pemberi bantuan hukum lainnya dan atau pembimbing kemasyarakatan.

Bahwa pada saat memeriksa anak korban atau anak saksi, hakim dapat memerintahkan agar anak dibawa keluar (Pasal 58 UU SPPA). Dalam hal anak korban atau anak saksi tidak dapat untuk memberikan keterangan di depan sidang pengadilan, hakim dapat memerintahkan anak korban atau anak saksi untuk didengar keterangannya di luar persidangan melalui perekaman elektronik yang dilakukan oleh pembimbing kemasyarakatan dengan dihadiri penyidik atau Penuntut Umum dan Advokat atau pemberi bantuan hukum, melalui pemeriksaan jarak jauh atau teleconference (Pasal 58 UU SPPA), serta masih banyak hal lagi hak-hak ABH yang diatur didalam UU SPPA, sebagai wujud representasi Negara dalam melindungi anak dalam perkara $\mathrm{ABH}$.

Terkait dengan fokus dari penelitian ini untuk perkara ABH (anak sebagai pelaku maupun anak sebagai korban tindak pidana), berdasarkan hasil wawancara dengan Kanit Perlindungan perempuan dan anak (PPA) Polres P. Ambon dan PP. Lease penyelesaian perkara anak sebagai pelaku sudah sesuai dengan apa yang dimanatkan dalam UU SPPA, dimana ketika Anak pelaku tindak pidana dalam menjalani pemeriksaan di PPA, hakhaknya sebagai anak sangatlah diperhatikan. Hal ini dapatlah dilihat dari mulai ada laporan, pihak penyidik dalam hal ini PPA langsung menghubungi Pembimbing Kemasyarakatan (PK) dari Balai Pemasyarakatan (Bapas) untuk dapat terlibat langsung dalam proses penyidikan terhadap anak pelaku tindak pidana. ${ }^{2}$ Hal inipun sejalan dengan apa yang disampaikan oleh Kanit PPA kepulauan Aru, selalu ada koordinasi dengan pihak Pembimbing Kemasyarakatan, Balai Pemasyarakatan dalam menangani anak yang berhadapan dengan hukum $(\mathrm{ABH}) .^{3}$

Ditambahkannya juga bahwa dalam memberikan keterangan kepada penyidik anak, anak pelaku tetap didampingi keluarga. Pertanyaan-pertanyaan yang diberikan haruslah dimengerti dan dipahami oleh anak. Anak pelaku ini tetaplah merasa nyaman, sekalipun dia adalah pelaku tindak pidana. Suasana yang diciptakan harus tetap terasa nyaman oleh anak. $^{4}$

Proses Diversi selalu dilakukan oleh PPA Polres P.Ambon PP. Lease dan PPA Polres Kepulauan Aru, melalui musyawarah dengan melibatkan Pelaku anak dan orang tuanya, korban dan orang tua korban, Pembimbing Kemasyarakatan dari Balai Pemasyarakatan (Bapas) dan Pekerja Sosial Profesional yang juga dapat melibatkan

${ }^{2}$ Hasil Wawancara dengan Kanit PPA Polres Pulau Ambon dan P.P Lease, Bripka Orpha Jambormias, tanggal 24 Oktober 2019, Pukul 13.30 WIT.

${ }^{3}$ Hasil wawancara dengan kanit PPA Polres Kepulauan Aru, Bripka Bripka Irsan Yusuf, tanggal 18 Oktober 2019, Pkl. 13.45 WIT

${ }^{4}$ Ibid

205 |S A S I Vo1. 26 No.2, A pril - Juni 2020 
Tenaga Kesejahteraan Sosial, dan/atau masyarakat. Dan apabila tidak ada kesepakatan untuk diversi maka proses tetap berjalan.

Untuk kepentingan terbaik bagi anak pelaku, sedapat mungkin dihindari anak pelaku untuk dilakukan penahanan. Terkait anak pelaku tindak pidana yang sudah berulang (residivis) untuk perkara-perkara tertentu misalnya tindak pidana pencurian maka penangannya bukan di unit PPA tetapi di Unit Reskrimum, perlakuannya sedikit berbeda dalam hal ini akan dilakukan penahanan (merupakan upaya terakhir) dengan pertimbangan anak tersebut berpotensi melarikan diri, tetapi ada pengecualinnya apabila ada jaminan dari keluarga dalam artian anak pelaku (residivis) telah menjalani pemulihan perilaku maupun pemulihan nama baik. Kiblatnya tetap pada UU SPPA. ${ }^{5}$

Selain itu juga dalam penegakan hukum yang melibatkan anak sebagai pelaku, vonis hakim selalu memberikan sanksi yang ringan misalnya diberikan sanksi $1 / 3$ dari hukuman pokok orang dewasa kemudian dikurangi 1/3 lagi. Misalnya ancaman pokok orang dewasa 15 tahun jaksa tuntut $1 / 3$ dari 15 tahun yaitu 5 tahun, maka putusan hakim 1/3 dari 5 tahun bisa 1,5 tahun maupun 2,5 tahun. Hal ini merupakan perwujudan dari asas kepentingan terbaik anak (anak sebagai pelaku tindak pidana) tetapi dalam hal ini hakim melihat berat-ringan kasus yang di sidangkan.

Misalnya dalam kasus pelecehan seksual maupun pemerkosaan dan dilakukan dalam berpacaran, hakim selalu mempertimbangkan bahwa tindak pidana dapat terjadi karena ada hubungan saling kenal, serta hubungan emosional. Contoh lain apabila anak pelaku berumur 15-17 tahun dan korbannya masih umur balita (3-5 tahun) hakim biasanya putus berdasarkan 1/3 dari ancaman pidana pokok. Apabila pelakunya orang dewasa, maka hakim selalu vonis di atas 5 tahun, untuk pelaku anak tidak lebih dari 5 $\operatorname{tahun}^{6}$

Secara empiris dalam penanganan perkara $\mathrm{ABH}$ yang telah di identifikasi kasusnya diketahui bahwa perkara ABH khususnya anak korban membutuhkan bantuan dari instansi-instansi terkait diantaranya dinas sosial, dinas kesehatan, maupun pihak yang lain yaitu Lembaga sosial Masyarakat (selanjutnya disebut LSM). Dalam hal ini, jika anak korban membutuhkan layanan sosial pihak PPA Polres Pulau Ambon dan P.P Lease maupun Polres Kepulauan Aru selalu melakukan koordinasi dengan dinas sosial, jika diperlukan akses kesehatan, maka dilakukan koordinasi dengan dinas kesehatan. Untuk pemerintah biasanya dalam penanganan perkara $\mathrm{ABH}$ (khusus anak sebagai korban) dilakukan koordinasi dengan Pusat Pelayanan Terpadu Pemberdayaan Perempuan dan Anak (selanjutnya disebut P2TP2A) kota Ambon. ${ }^{7}$

Proses pendampingan Anak korban tindak pidana yang dilakukan oleh P2TP2A kota Ambon ${ }^{8}$ dan P2TP2A Kabupaten Kepulauan Aru ${ }^{9}$, yakni didasari oleh adanya laporan oleh korban (yang diwakilkan orang tua). Pada saat menerima laporan dan mengetahui kronologis tindak pidana yang terjadi berikut orang yang diduga pelakunya, maka dari pihak P2TP2A menanyakan kepada pihak keluarga apakah kasus tersebut mau diteruskan untuk diproses secara hukum atau tidak, dengan konskekuensinya bahwa perkara $\mathrm{ABH}$ ini jika diperiksa dalam proses peradilan, dapat terganggu psikis anak

5 Ibid

${ }^{6}$ Hasil wawancara...Op. Cit Bripka Orpha Jambormias

7 Ibid

8 Hasil wawancara dengan Ibu Ina Soelisa, Ketua harian P2TP2A Ambon, tanggal 18 Oktober 2019, Pkl.11. 15 WIT.

9 Hasil wawancara dengan Ibu R.Putnarubun Komen, salah satu pendamping anak korban di P2TP2A Kep. Aru, tanggal 17 Oktober 2019 Pkl 17.45 WIT 
sebagai korban, karena jika masuk lingkaran Sistem Peradilan Pidanan (selanjautya disebut SPP), maka hal ini bisa menjadi konsumsi publik khalayak ramai. Apabila keluarga menyetujui hal ini, maka P2TP2A akan melakukan pendampingan terhadap anak korban mulai dari tahap penyidikan polisi sampai dengan penjatuhan sanksi pidana lewat putusan hakim/pengadilan (pendampingan dilakukan pada setiap tahapan pemeriksaan perkara).

Berikut ini akan digambarkan anak sebagai korban tindak pidana yang didampingi oleh P2TP2A kota Ambon dan P2TP2A Kepulauan Aru sebagai berikut:

Tabel 3.

Perkara ABH (Anak Sebagai Korban)

Tahun 2018/2019

\begin{tabular}{|l|l|c|c|}
\hline \multirow{2}{*}{ No } & \multicolumn{1}{|c|}{ Kasus } & \multicolumn{2}{c|}{ Tahun } \\
\cline { 3 - 4 } & & 2018 & 2019 \\
\hline 1. & Pertubuhan Anak di Bawah Umur & 3 & 28 \\
\hline 2. & Pencabulan & 4 & 6 \\
\hline 3 & Kekerasan terhadap anak & 3 & 24 \\
\hline 4 & Penelantaran Anak & 2 & 6 \\
\hline 5 & Sodomi & 1 & - \\
\hline 6 & TPPO & - & - \\
\hline 7 & Prostitusi Anak & 2 & 2 \\
\hline 8 & Melarikan Anak di bawah umur & 2 & 2 \\
\hline 9 & Eksploitasi Anak & 2 & 2 \\
\hline
\end{tabular}

Sumber data: P2TP2A Kota Ambon (Data Terakhir Oktober 2019)

Tabel 4.

Perkara ABH (Anak Sebagai Korban)

Tahun 2018/2019

\begin{tabular}{|l|l|c|c|}
\hline \multirow{2}{*}{ No } & \multicolumn{1}{|c|}{ Kasus } & \multicolumn{2}{c|}{ Tahun } \\
\cline { 3 - 4 } & & 2018 & 2019 \\
\hline 1. & Setubuh Anak di Bawah Umur & 5 & 20 \\
\hline 2. & Pencabulan & 3 & 5 \\
\hline 3 & Kekerasan terhadap anak & 2 & 20 \\
\hline 4 & Penelantaran Anak & 1 & 6 \\
\hline 5 & Sodomi & 1 & 1 \\
\hline 6 & TPPO & - & - \\
\hline 7 & Prostitusi Anak & 1 & 2 \\
\hline 8 & Melarikan Anak di bawah umur & 1 & 1 \\
\hline 9 & Eksploitasi Anak & 3 & 5 \\
\hline
\end{tabular}

Sumber data: P2TP2A Kabupaten Aru (Dobo) (Data Terakhir Oktober 2019)

Dari kedua tabel diatas tergambarkan bahwa pendampingan terhadap anak korban tindak pidana telah dilakukan, baik pendampingan yang dilakukan oleh P2TP2A Kota Ambon maupun P2TP2A Kepulauan Aru, serta dari segi kuantitas tidak terlihat perbedaan yang mencolok diantara kedua lokasi ini. Untuk perkara ABH (anak korban), tindak pidana persetubuhan terhadap anak yang menempati posisi-posisi yang paling 
tinggi. Hal ini menggambarkan bahwa untuk jenis tindak pidana persetubuhan, anak sangat rentan menjadi korban.

Terkait dengan kepentingan terbaik bagi anak, untuk anak korban idealnya sedapat mungkin memberikan keadilan bagi korban anak, baik keadilan hukum maupun keadilan dalam memperoleh kehidupan yang layak ditengah masyarakat. Sehingga pada saat selesainya proses peradilan, proses rehabilitasi, konseling, trauma konseling terhadap anak korban dan ketika mereka kembali ke masyarakat dengan tanpa adanya celaan dari masyarakat, sebaliknya mereka harus didukung keberadaanya di tengah-tengah masyarakat

Proses ini agak sulit bagi anak korban pemerkosaan maupun anak korban pelecehan seksual karena norma-norma yang ada di masyarakat memandang anak korban pemerkosaan sebagai "anak yang sudah rusak masa depannya". Selain itu juga anak korban pelecehan seksual maupun anak korban pemerkosaan juga sering mendapatkan stigma negatif dari penyidik, sehingga pendampingan untuk anak korban pelecehan seksual maupun pemerkosaan harus mendapat porsi yang lebih. Ini merupakan tanggungjawab bukan hanya pedamping anak korban tetapi juga keluarga maupun masyarakat untuk tetap mendukung mereka untuk merasa diri mereka tetap berharga atau positif thinking terhadap diri mereka sendiri, mendapatkan kembali rasa kepercayaan diri serta menghargai mereka sebagaimana menghargai manusia yang lain. Tanpa membiarkan mereka hidup sendiri atau mendiskriminasi mereka. ${ }^{10}$

Berdasarkan hasil penelitian di P2TP2A Kepulauan Aru (Dobo) juga didapatkan bahwasanya anak sebagai korban tindak pidana, pada tahapan penyidikan kebebasan dan hak-hak fundamental mereka untuk terbebas dari segala bentuk diskriminasai selama menjalani atau menempuh proses peradilan tidak didapatkannya secara maksimal. Hal ini terlihat dari beragam stigma menyalahkan korban, pembebanan pembuktian, konfrontir dengan tersangka/ pelaku masih terus dilakukan aparat penegak hukum. Korban anak juga seringkali tidak mendapatkan informasi yang memadai mengenai hak-haknya, serta tidak mendapatkan bantuan hukum (pendamping) dan pemulihan baik selama dan setelah proses peradilan. ${ }^{11}$

Berdasarkan rangkaiaan pemaparan diatas, terlihat bahwa pemenuhan kepentingan terbaik bagi anak pada perkara $\mathrm{ABH}$ (anak sebagai pelaku maupun anak sebagai korban), perwujudannya harus didukung oleh semua stakeholder terkait, sehingga hak-hak anak pada perkara ini dapat di implementasi pada semua tahapan pemeriksaan perkara sesuai dengan amanah UU SPPA maupun UU terkait. Tidak cukup disitu saja, pemenuhan kepentingan terbaik juga harus terus didukung ketika $\mathrm{ABH}$ (Anak pelaku maupun anak korban) kembali ke masyarakat (hal ini harus mendapat perhatian lebih). Dengan kata lain ketika $\mathrm{ABH}$ tidak didukung untuk survive maka pemenuhan kepentingan terbaik bagi anak tidak berjalan sebagaimana mestinya.

\section{Kendala-kendala dalam pemenuhan kepentingan terbaik bagi anak sebagai pelaku dan anak sebagai korban}

Anak adalah bagian yang tidak terpisahkan dari keberlangsungan hidup manusia dan keberlangsungan sebuah bangsa dan Negara. Dengan peran anak yang penting itu, hak anak telah secara tegas dinyatakan dalam konstitusi, bahwa negara menjamin setiap

\footnotetext{
10 Hasil wawancara...Op. Cit Ibu Ina Soelisa

11 Hasil wawancara...Op. Cit Bripka Irsan Yusuf
} 
anak berhak atas kelangsungan hidup, tumbuh dan berkembang serta berhak atas perlindungan dari kekerasan dan diskriminasi.

Setiap anak memerlukan pembinaan dan perlidungan dalam rangka menjamin pertumbuhan dan perkembangan fisik, mental dan sosial secara utuh, serasi, selaras dan seimbang, termasuk didalamnya anak yang berhadapan dengan hukum $(\mathrm{ABH})$, baik itu terhadap anak yang berkonflik dengan hukum (anak sebagai pelaku tindak pidana) maupun anak sebagai korban tindak pidana. Esensi yang paling mendasar dalam peradilan anak adalah pemeriksaan yang dilakukan oleh polisi, jaksa, hakim dan pejabat lainnya aktivitasnya bertumpu pada aspek pembinaan, perlindungan serta didasarkan pada prinsip kepentingan anak tanpa mengurangi kepentingan masyarakat. Hal ini merupakan bentuk perlindungan dari negara terhadap anak.

Namun harapan pembuat undang-undang tidak berbanding lurus dengan apa yang diharapkan, yang mana realitas penyelesaian perkara yang melibatkan anak sebagai pelaku maupun anak sebagai korban, terdapat berbagai kendala dalam mengaktualisasikannya. Hal ini didapati penulis ketika melakukan penelitian pada instansi Polres P. Ambon dan P.P Lease, P2TP2A Kota Ambon, Polres Kepulauan Aru maupun P2TP2A Kepulauan Aru, yang akan digambarkan dalam tabel sebagai berikut:

Tabel 5.

\section{Kendala-Kendala Penanganan Perkara ABH}

\begin{tabular}{|c|c|c|}
\hline No & Nama Instansi & Kendala \\
\hline 1 & $\begin{array}{l}\text { Polres P. Ambon dan } \\
\text { Pulau-Pulau Lease }\end{array}$ & $\begin{array}{l}\text { 1) Minimnya SDM Penyidik Perlindungan } \\
\text { Perempuan dan Ank (PPA) } \\
\text { 2) Fasilitas/Insfrastruktur belum memadai } \\
\text { 3) Anggaran penanganan Perkara ABH tidak cukup }\end{array}$ \\
\hline 2 & P2TP2A Ambon & $\begin{array}{l}\text { 1) Sarana dan fasilitas belum tersedia secara baik } \\
\text { 2) Sumber Daya Manusia (SDM) baik penyidik PPA } \\
\text { maupun pendamping korban belum mumpuni } \\
\text { 3) Aggaran tidak mencukupi } \\
\text { 4) Kurangnya dukungan dari masyarakat atas } \\
\text { pemulihan psikis anak korban tindak pidana }\end{array}$ \\
\hline 3 & Polres Kepulauan Aru & $\begin{array}{l}\text { 1) Fasilitas/Sarana prasarana belum memadai } \\
\text { 2) Minimnya penyidik PPA } \\
\text { 3) Ketidakpahaman hukum oleh orang tua terkait } \\
\text { dengan regulasi/aturan yang melindungi anak }\end{array}$ \\
\hline 4 & $\begin{array}{l}\text { P2TP2A } \\
\text { Aru }\end{array}$ & $\begin{array}{l}\text { 1) Sarana dan prasarana belum memadai } \\
\text { 2) SDM Penyidik belum mumpuni } \\
\text { 3) SDM pendamping korban anak belum mumpuni } \\
\text { 4) Proses pendampingan anak korban, terbatas hanya } \\
\text { dalam proses peradilan }\end{array}$ \\
\hline
\end{tabular}

Berdasarkan tabel diatas, terlihat bahwasanya ada beberapa kendala yang dihadapi dalam penanganan kasus ABH (anak sebagai pelaku maupun anak sebagai korban tindak pidana) baik yang dihadapi oleh Polres P.Ambon dan P.P Lease, Polres Kepulauan Aru, P2TP2A Kota Ambon serta P2TP2A Kepulauan Aru, sebagai berikut:

a) Minimnya jumlah penyidik PPA 
Jumlah penyidik PPA Polres. P. Ambon dan P.P lease berjumlah 7 (tujuh) orang. Hal ini tidak sebanding dengan banyaknya perkara $\mathrm{ABH}$ yang ditangani dalam 1 tahun (2019) yang mana perkara $\mathrm{ABH}$ yang ditangani oleh unit ini berjumlah 256 kasus dan yang sudah terselesaikan 202 kasus (data sampai bulan Oktober 2019) ${ }^{12}$;

b) Fasilitas/Insfrastruktur yang tidak memadai

Fasilitas yang tidak memadai, sehingga amanah undang-undang untuk penangan $\mathrm{ABH}$ tidak dapat di implemantasikan secara maksimal yang mana di Polres P.Ambon dan P.P. Lease tidak memiliki ruang konseling untuk $\mathrm{ABH}$, ruang diversi anak, sel anak juga tidak dimiliki ${ }^{13}$, hal yang sama juga dihadapi oleh Polres Kepulauan $\mathrm{Aru}^{14}$, serta belum ada sekretariat yang memadai, maupun rumah aman buat tempat berlindung sementara buat korban anak ${ }^{15}$

c) Sumber Daya Manusia (SDM) baik penyidik PPA maupun pendamping korban belum mumpuni

Kerjasama antara P2TP2A Ambon dengan unit PPA Polres maupun PPA Polda Mauluku terkendala dengan SDM Penyidik PPA yang belum memadai. ${ }^{16}$ P2TP2A Kota Ambon dibawah dinas Pemberdayaan Perempuan dan perlindungan Anak Masyarakat dan Desa (DP3AMD) belum mempunyai sumber daya manusia yang memadai untuk melakukan pendampingan terhadap anak sehingga walikota Ambon meminta bantuan pendampingan dari orang-orang sipil (profesional) dalam melakukan pendampingan ${ }^{17}$

d) Minimnya anggaran dalam penyelesaian perkara $\mathrm{ABH}$

Anggaran yang didapatkan oleh unit PPA Polres P. Ambon dan P.P Lease sebatas 35 kasus, hal ini berbanding terbalik dengan perkara $\mathrm{ABH}$ yang di tangani sejumlah 235 kasus. Aggaran tidak mencukupi dalam melakukan pendampingan maupun halhal lain yang berhubungan dengan penganan anak sebagai korban. ${ }^{18}$

e) Ketidakpahaman hukum oleh orang tua terkait dengan regulasi/aturan yang melindungi anak

Kekerasan sudah menjadi budaya di Maluku, sehingga harus diutamakan untuk diatasi atau di minimalisir dan hal ini tidak mudah. Tantangan utama, ketika terjadi kekerasan didalam keluarga misalnya kekerasan terhadap anak yang dilakukan oleh orang tua, ada anggapan yang telah membudaya bahwa anak adalah milik orang tua sehingga orang tua bebas untuk melakukan apa saja terhadap anak (korban kekerasan) kenapa harus di intervensi oleh pihak luar ?. Hal ini merupakan ketidakpahaman hukum oleh orang tua terkait dengan regulasi/aturan yang melindungi anak. Padahal anak adalah milik negara setelah tercantum didalam Kartu keluarga (KK) yang mana anak adalah individu yang hak-haknya dijamin oleh undang-undang (hak untuk hidup dengan aman dan layak buat anak) ${ }^{19}$

f) Proses pendampingan anak sebagai korban tindak pidana, terbatas hanya dalam proses peradilan

Pendampingan dari psikiter terbatas hanya dalam proses peradilan, setelah selesinya proses peradilan anak tidak lagi didampingi. Misalnya saja orang-orang profesional yang melakukan pendampingan terhadap $\mathrm{ABH}$ khusus anak orientasinya hanya uang, padahal untuk melakukan pendampinagan $\mathrm{ABH}$ khusus anak korban

12 Hasil Wawancara...Op. Cit Bripka Orpha Jambormias

13 Ibid

14 Hasil wawancara,... Op. Cit Bripka Irsan Yusuf

15 Hasil wawancara..., Op. Cit Ibu Ina Soelisa

16 Ibid

17 Ibid

18 Hasil wawancara...Op. Cit Ibu Ina Soelisa

19 Hasil wawancara..., Op. Cit Ibu R. Putnarubun Komen 
merupakan pekerjaan kemausiaan dan butuh kerelaan dalam menjalani proses ini, hal ini yang belum terlihat ${ }^{20}$

g) Kurangnya dukungan dari masyarakat dalam pemulihan psikis anak korban tindak pidana

Proses ini agak sulit bagi anak korban pemerkosaan maupun anak korban pelecehan seksual karena norma-norma yang ada di masyarakat memandang anak korban pemerkosaan sebagai "anak yang sudah rusak masa depannya". Selain itu juga anak korban pelecehan seksual maupun anak korban pemerkosaan juga sering mendapatkan stigma negatif dari penyidik, sehingga pendampingan untuk anak korban pelecehan seksual maupun pemerkosaan harus mendapat porsi yang lebih. Ini merupakan tanggungjawab bukan hanya pedamping anak korban tetapi juga keluarga maupun masyarakat untuk tetap mendukung mereka untuk merasa diri mereka tetap berharga atau positif thinking terhadap diri mereka sendiri, mendapatkan kembali rasa kepercayaan diri serta menghargai mereka sebagaiamana menghargai manusia yang lain. Tanpa membiarkan mereka hidup sendiri atau mendiskriminasi mereka. ${ }^{21}$

\section{P E N U T U P}

Berdasarkan hasil penelitian terkait dengan pemenuhan kepentingan terbaik bagi anak pada perkara $\mathrm{ABH}$ (anak sebagai pelaku maupun anak sebagai korban) didapatkan bahwasanya perwujudannya harus di dukung oleh semua stakeholder terkait sehingga hak-hak anak pada perkara ini dapat di implementasi pada semua tahapan pemeriksaan perkara sesuai dengan amanah UU SPPA maupun UU terkait. Tidak cukup disitu saja, pemenuhan kepentingan terbaik juga harus terus didukung ketika $\mathrm{ABH}$ (Anak pelaku maupun anak korban) kembali ke masyarakat (hal ini harus mendapat perhatian lebih). Dengan kata lain ketika $\mathrm{ABH}$ tidak didukung untuk survive maka pemenuhan kepentingan terbaik bagi anak tidak berjalan sebagaimana mestinya. Adapun kendalakendala dalam pemenuhan kepentingan terbaik bagi anak sebagai pelaku dan anak sebagai korban adalah:

1) Minimnya jumlah penyidik PPA;

2) Fasilitas/Insfrastruktur yang tidak memadai;

3) Sumber Daya Manusia (SDM) baik penyidik PPA maupun pendamping korban belum mumpuni;

4) Minimnya anggaran dalam penyelesaian perkara $\mathrm{ABH}$;

5) Ketidakpahaman hukum oleh orang tua terkait dengan regulasi/aturan yang melindungi anak;

6) Proses pendampingan anak sebagai korban tindak pidana, terbatas hanya dalam proses peradilan;

7) Kurangnya dukungan dari masyarakat dalam pemulihan psikis anak korban tindak pidana.

\section{DAFTAR PUSTAKA}

\section{Buku}

[1] Makarao, M. T., dkk. (2013). Hukum Perlindungan Anak dan Penghapusan

${ }^{20}$ Hasil wawancara dengan Ibu Ninik Kusnati,salah satu pendamping anak korban di P2TP2A Kota Ambon, tanggal 17 Oktober 2019, Pkl 10.00WIT

21 Hasil wawancara...Op. Cit Ibu Ina Soelisa 
Kekerasan Dalam Rumah Tangga, Jakarta: Rineka Cipta

\section{Wawancara}

[2] Hasil Wawancara dengan Kanit PPA Polres Pulau Ambon dan P.P Lease, Bripka Orpha Jambormias, tanggal 24 Oktober 2019, Pukul 13.30 WIT.

[3] Hasil wawancara dengan kanit PPA Polres Kepulauan Aru, Bripka Bripka Irsan Yusuf, tanggal 18 Oktober 2019, Pkl. 13.45 WIT

[4] Hasil wawancara dengan Ibu Ina Soelisa, Ketua harian P2TP2A Ambon, tanggal 18 Oktober 2019, Pkl.11. 15 WIT.

[5] Hasil wawancara dengan Ibu R.Putnarubun Komen, salah satu pendamping anak korban di P2TP2A Kep. Aru, tanggal 17 Oktober 2019 Pkl 17.45 WIT

[6] Hasil wawancara dengan Ibu Ninik Kusnati,salah satu pendamping anak korban di P2TP2A Kota Ambon, tanggal 17 Oktober 2019, Pkl 10.00WIT 